\title{
定容燃焼器を用いた副室式点火の基礎燃焼特性に関する研究
}

\author{
上野 聖矢 ${ }^{* 1}$, 佐竹 洋輔*2, 高山 泰佳 ${ }^{* 1}$, 嶋田 不美生 ${ }^{* 2}$, 田上 公俊*3, 森吉 泰生 ${ }^{* 4}$
}

\section{A fundamental study of prechamber combustion characteristics in a constant volume combustion chamber}

\author{
Seiya UENO $^{* 1}$, Yosuke SATAKE ${ }^{* 2}$, Taiga TAKAYAMA ${ }^{* 1}$, \\ Fumio SHIMADA ${ }^{* 2}$, Kimitoshi TANOUE ${ }^{* 3}$ and Yasuo MORIYOSHI ${ }^{* 4}$

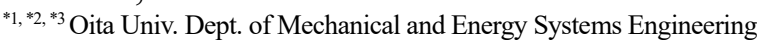 \\ 700 Dannoharu, Oita 870-1192, Japan \\ ${ }^{*}$ Chiba Univ. Graduate School of Engineering \\ 1-33 Yayoi-cho, Inage-ku, Chiba 263-0022, Japan
}

Received: 10 February 2020; Revised: 24 April 2020; Accepted: 13 August 2020

\begin{abstract}
The prechamber combustion characteristics were studied using a constant volume combustion chamber to improve the efficiency of cogeneration natural gas engines. The torch flames generated by a prechamber were used to investigate the effect that a prechamber has on the main combustion. In our previous study, we observed the correlation between the torch flame and the main flame (which is a so-called "prechamber combustion") as well as the knocking phenomena for various prechamber configurations using a rapid compression and expansion machine (RCEM). In this study, we have investigated the effect of prechamber combustion on main chamber combustion characteristics using a constant volume combustion chamber, especially to study the ignitability of the main chamber.
\end{abstract}

Keywords : Combustion, Prechamber, RCEM, Ignition, Jet flame

\section{1. 緒言}

現在，地球規模での環境問題，エネルギ一資源枯渇問題が深刻化する中，環境低負荷な発電システムとして， 多様な燃料から電気エネルギーと熱エネルギーを併給可能なコージェネレーション（コジェネ）が注目されてい る(資源エネルギー庁，2003).コジェネは総合効率が約 80 \%に達し，分散型エネルギーシステムとして適してい る.コジェネのさらなる普及のためには，発電効率を上げて熱電比の可塑性を高め，需要により柔軟に対応する 必要がある. 我が国においてコジェネの総発電容量の約 $49 \%$ は天然ガスが用いられ，また設置台数ではガスエン ジンが約 $65 \%$ と最も多くなっていることから，40\%程度の天然ガスエンジンの高効率化が重要な課題となる. ガ スエンジンの高効率化の有効な一手段として希薄燃焼があげられるが，燃焼速度の低下や失火といった問題が生 じる．この対策としてガスエンジンでは「副室式点火」を用いて希薄燃焼時の点火と燃焼促進を実現している. 副室式点火は，主燃焼室とは別に小型の副室（主室の $5 \%$ 以下程度）を設け，副室で燃焼させたガスをトーチ火 炎として噴出させることで，主燃焼室内の希薄混合気を点火，燃焼させるという点火方式である．ガスエンジン の燃焼状態は副室からのトーチ火炎の噴出現象に依存するため，ガスエンジンの性能向上には副室点火燃焼の現 象を把握する必要がある．副室点火に関する研究はこれまで多くなされているが(Roethlisberger and Favrat, 2002, Heyne et al., 2009, Jamrozik, 2015)，主に実エンジンを対象に行われているため，副室形状を変えた研究や，トーチ 火炎の形態と主室内の燃焼状態を調べた研究例は少ない.

No.20-00039 [DOI:10.1299/transjsme.20-00039], J-STAGE Advance Publication date : 24 August, 2020

*1 学生員, 大分大学大学院 工学専攻 機械エネルギー工学コース（† 870-1192 大分県大分市旦野原 700）

*2 大分大学

*3 正員，フェロー，大分大学

*4 正員, フェロー, 千葉大学大学院（干263-0022 千葉県千葉市稲生区弥生町 1-33）

E-mail of corresponding author: tanoue@oita-u.ac.jp 
Ueno, Satake, Takayama, Shimada, Tanoue and Moriyoshi,

Transactions of the JSME (in Japanese), Vol.86, No.889 (2020)

著者らは既報(Tanoue et al., 2017)で，急速圧縮澎張装置 (Rapid Compression Expansion Machine : RCEM) を用いた 可視化実験によりガスエンジンの副室式燃焼特性について調べた．本研究では副室を備えた定容燃焼器を用いて 主室内の燃焼に及ぼす副室点火の影響に関してさらに体系的な考察を行った.

\section{2. 実験装置および方法}

\section{$2 \cdot 1$ 実験装置}

本研究では副室式点火による主室の燃焼特性を観察するため, 図 1 に示すような定容燃焼器 (田上他, 2012) を用いた．本燃焼装置は容積が約 13L の主燃焼室（以降，主室）(2)の内部に副室(3)が設置されている．また，主 室内下部には混合気を均一に擋拌するために, サーボモータにより駆動するファンが取り付けられている.さら に主室および副室内部に圧力センサーを装着している.

図 2 に副室の断面図を示寸．副室容積は主室容積の $0.65 \%$ に相当する $0.085 \mathrm{~L}$ である. フロントプレート(6)を交 換することにより，噴孔径，噴孔数を変更でき，またバックプレート(7)の交換により各種プラグ等に対応するこ とが出来る. また副室内には圧力を計測する圧力センサー8 と点火プラグ(9)が装着されている．点火プラグは， 市販の自動車用点火プラグを用い，点火装置は市販の自動車用点火装置を用いて燃焼実験を行った.

図 3(a)に噴孔数が一つ（以下，一孔）, 図 3(b)に噴孔数が二つ（以下，二孔）のフロントントプレートの断面図 を示す．フロントプレートは，噴孔径 $4.2 \mathrm{~mm}$ の一孔および二孔，さらに噴孔径 $4.2 \mathrm{~mm}$ の二孔と噴孔総面積をそ ろえた噴孔径 $6.4 \mathrm{~mm}$ の一孔の 3 種類のプレートを用意した.

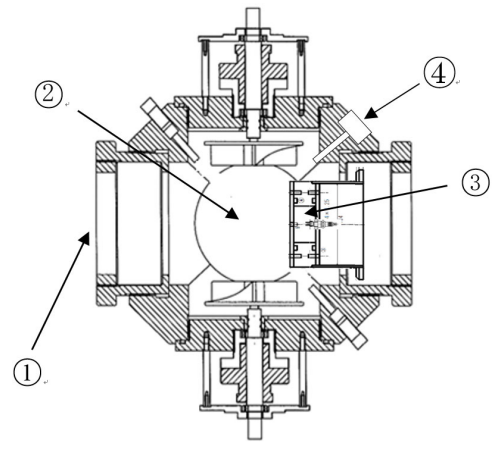

(1) Observation window (3)Pre-chamber (2) Main chamber

(4) Pressure gauge

Fig.1 Cross-section view of combustion chamber.

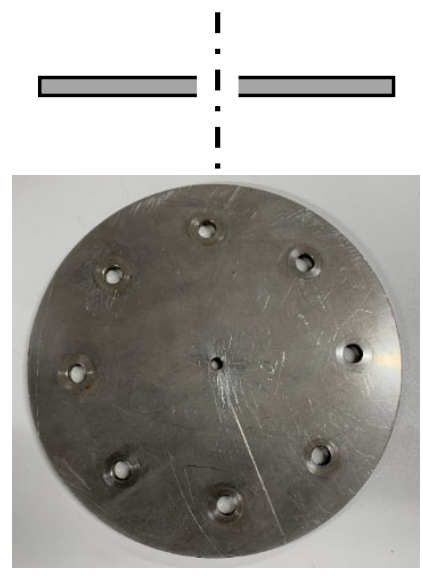

(a) 1hole

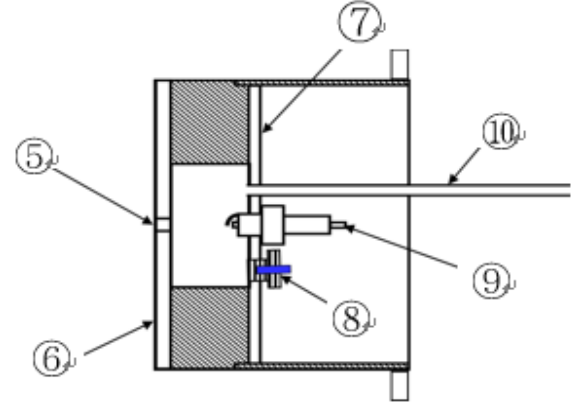

$\begin{array}{ll}\text { (5) Orifice } & \text { 8Pressure gauge } \\ \text { (6) Nozzle plate } & \text { (9Ignition plug } \\ \text { (7)Back plate } & \text { (10Injection nozzle }\end{array}$

Fig.2 Cross-section view of pre-chamber.

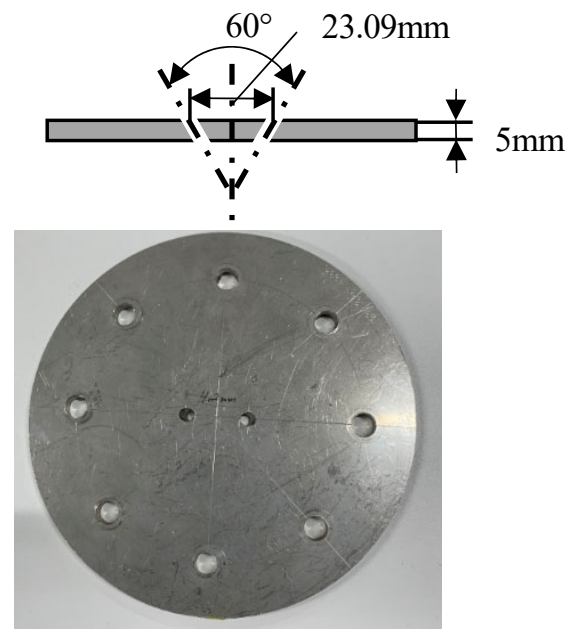

(b) 2 holes.

Fig.3 Pictures of nozzle plate. 
Ueno, Satake, Takayama, Shimada, Tanoue and Moriyoshi,

Transactions of the JSME (in Japanese), Vol.86, No.889 (2020)

\section{$2 \cdot 2$ 実験方法}

本実験ではまず主室に予混合気を形成後，予混合気タンクを用いて副室の燃料充填を行う．予混合気を主室と 副室に形成後，副室内に設けた点火プラグ9により点火し副室からの噴流（トーチ火炎と同義）により主室内を 燃焼させる．主燃焼室の水平 4 方向には直径 $150 \mathrm{~mm}$ の石英観測空(1)が備えられており，高速度カメラを用いた シャドウグラフ法により主室内の燃焼を観測した．また，圧力計により主室内，副室内の点火後の圧力変化を観 測した。燃料についてはメタンを用いた。

\section{3. 実験結果および考察}

\section{$3 \cdot 1$ 可視化による主室内の燃焼の観察}

本研究では, 副室を設けた定容燃焼器を用いて噴流形成および主室内燃焼に及ぼす初期圧力, 噴孔径, 当量比 の影響を調べる．初めに主室内のシャドウグラフ法による可視化により，各条件における噴流形状と主室内の燃 焼の様子を観察した.

表 1 に実験条件を示寸．燃料はメタンと空気の予混合気を用いて当量比は $\Phi=0.8, \Phi=1.0$ とした．また，副室 内と主室内の当量比は同一としている．また，表 2 に高速度カメラで撮影したメタンの各条件での着火有無の結 果を示す．着火の有無に関しては画像と燃焼室内の圧力波形により判定した.

Table 1 Experimental condition.

\begin{tabular}{|c|c|}
\hline Fuel & $\mathrm{CH}_{4}$ \\
\hline Equivalent ratio & $\Phi=0.8 / \Phi=1.0$ \\
\hline Initial pressure & $0.3 \mathrm{MPa} / 0.5 \mathrm{MPa}$ \\
\hline Temperature & $298 \mathrm{~K}$ \\
\hline Number of holes & 1 hole $/ 2 \mathrm{hole}$ \\
\hline Hole diameter & $4.2 \mathrm{~mm} / 6.4 \mathrm{~mm}$ \\
\hline
\end{tabular}

Table 2 Summary of experimental results.

\begin{tabular}{|c|c|c|c|c|}
\hline Hole diameter & Hole number & Equivalence ratio & $0.3 \mathrm{MPa}$ & $0.5 \mathrm{MPa}$ \\
\hline \multirow{3}{*}{$4.2 \mathrm{~mm}$} & \multirow{3}{*}{ 1hole } & $\Phi=0.8$ & $\bigcirc$ & $\bigcirc$ \\
\cline { 3 - 5 } & \multirow{2}{*}{ 2hole } & $\Phi=1.0$ & $\times$ & $\bigcirc$ \\
\cline { 3 - 5 } & & $\Phi=0.8$ & $\bigcirc$ & $\bigcirc$ \\
\hline \multirow{2}{*}{$6.4 \mathrm{~mm}$} & \multirow{2}{*}{ 1hole } & $\Phi=1.0$ & $\bigcirc$ & $\bigcirc$ \\
\cline { 3 - 5 } & & $\Phi=0.8$ & $\bigcirc$ & $\bigcirc$ \\
\hline
\end{tabular}

図 4(a) (e)に副室から主室に噴出後 $2 \mathrm{~ms}$ ごとの噴流および主室内燃焼のシャドウグラフの画像を各実験条件に 対して示す. 図 4(a)から当量比 1 , 初期圧力 $0.3 \mathrm{MPa}$ の条件では副室からの噴流は確認できるものの, 主室内の燃 焼には至っていないが, 図 4(b)から初期圧力を $0.5 \mathrm{MPa}$ まで上げると, 主室内が着火することがわかる.このこと から, 初期圧力が高いほど, 主室内の着火が促進されることがわかる. また, 図 4(c)から初期圧力 0.3MPa であつ ても当量比を 0.8 まで下げると, 着火に至った。これは後述のように副室からの噴流速度の差異が主室内着火の 有無に影響を及ぼしたものと推察される. 図 4(a)の着火しない条件に対して, 噴孔数を二孔にした場合 (図 4(d)), および噴孔面積を広げた場合，（図4(e)）のどちらも主室内の着火が確認された。両者とも噴孔総面積を広げる ことで，副室からの噴流速度が減少し，主室内が着火したものと推察される. 
Ueno, Satake, Takayama, Shimada, Tanoue and Moriyoshi,

Transactions of the JSME (in Japanese), Vol.86, No.889 (2020)

$2 \mathrm{~ms}$

$4 \mathrm{~ms}$

$6 \mathrm{~ms}$

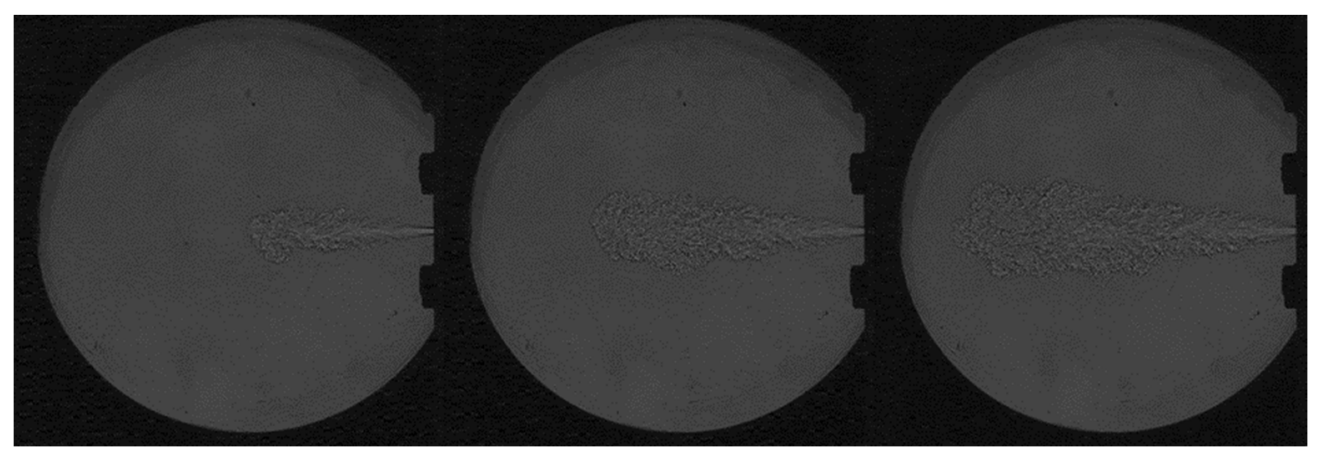

$8 \mathrm{~ms}$

$10 \mathrm{~ms}$

$12 \mathrm{~ms}$

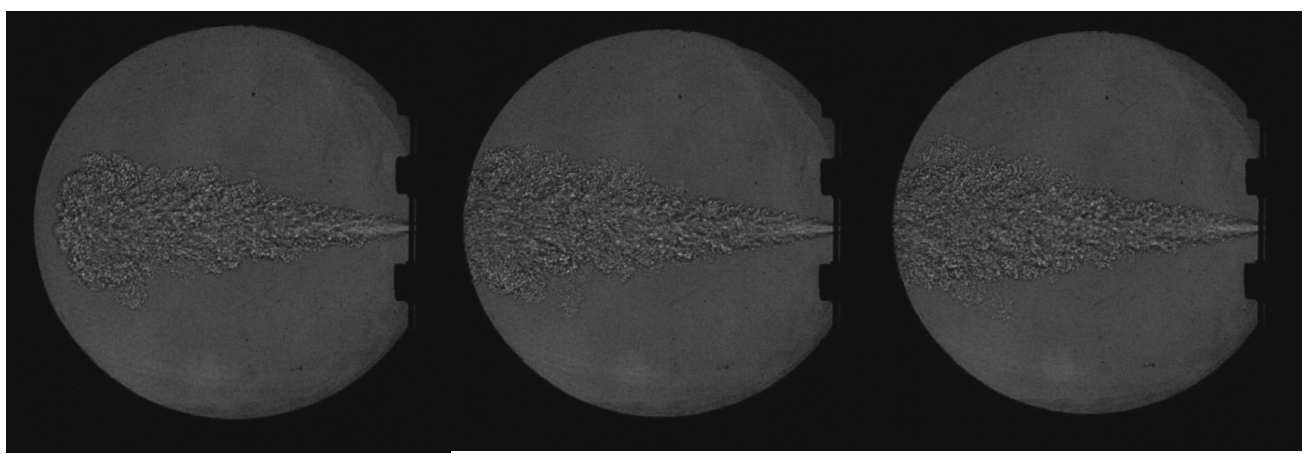

(a) $4.2 \mathrm{~mm} \times 1$ hole $\Phi=1.0,0.3 \mathrm{MPa}$.

$2 \mathrm{~ms}$

$4 \mathrm{~ms}$

$6 \mathrm{~ms}$

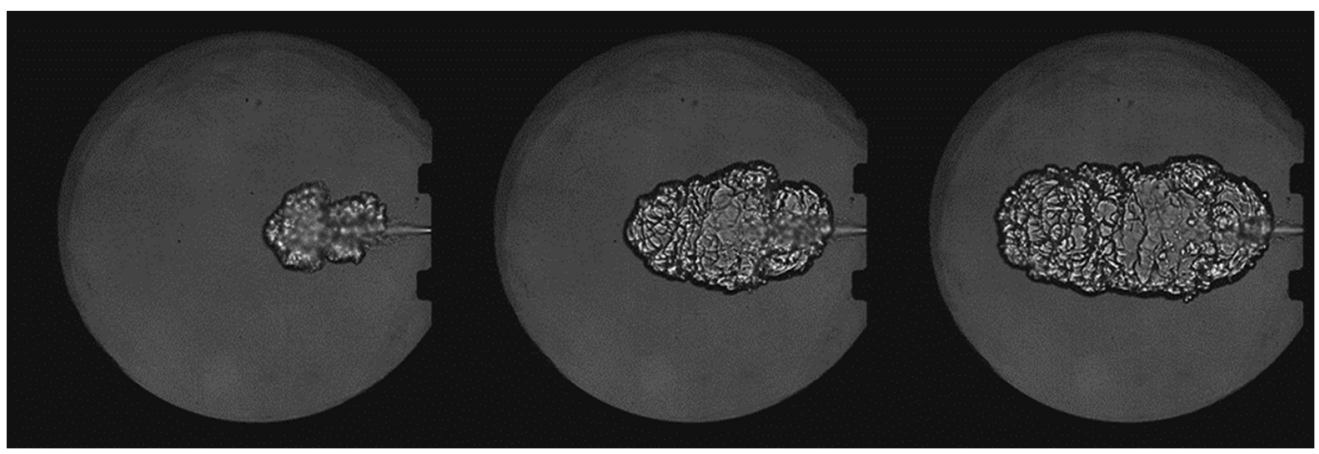

$8 \mathrm{~ms}$

$10 \mathrm{~ms}$

$12 \mathrm{~ms}$

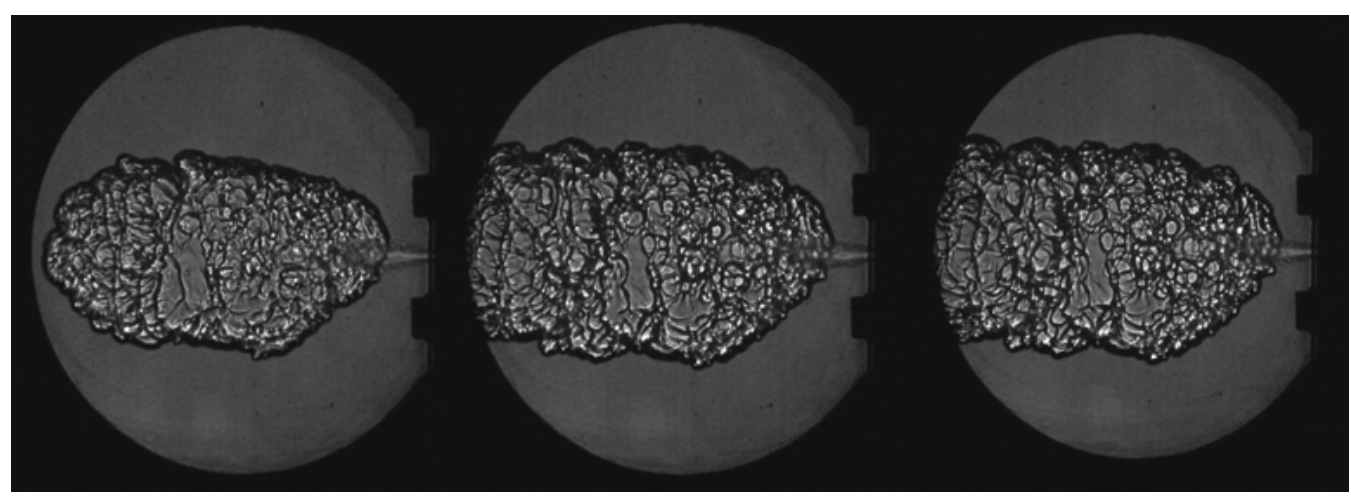

(b) $4.2 \mathrm{~mm} \times 1$ hole $\quad \Phi=1.0,0.5 \mathrm{MPa}$. 
Ueno, Satake, Takayama, Shimada, Tanoue and Moriyoshi,

Transactions of the JSME (in Japanese), Vol.86, No.889 (2020)

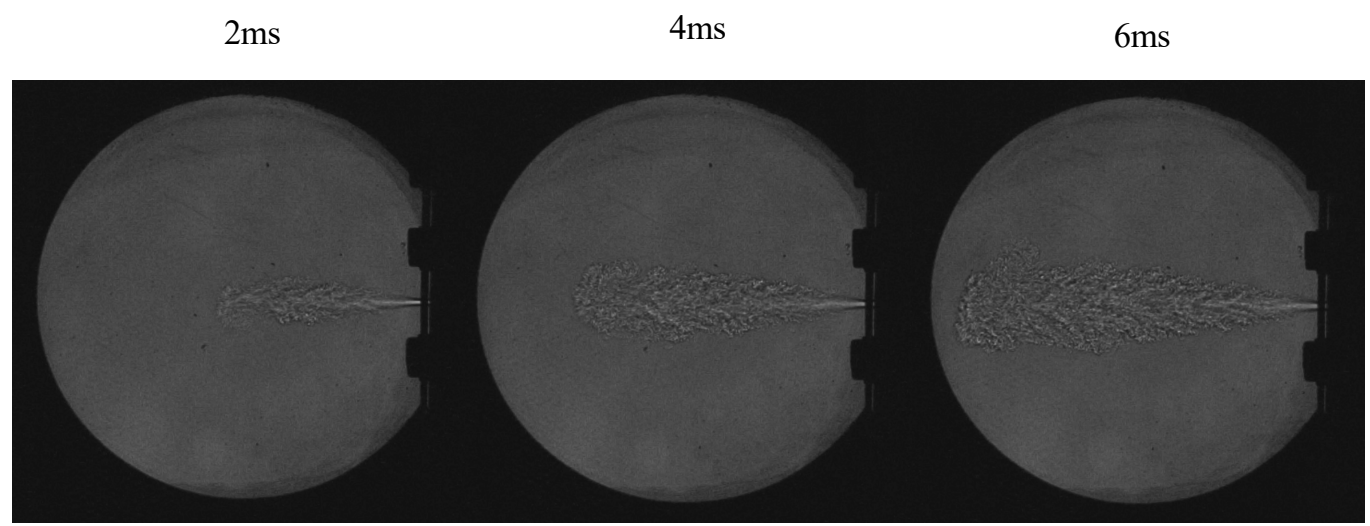

$60 \mathrm{~m}$

$62 \mathrm{~m}$

$64 \mathrm{~m}$

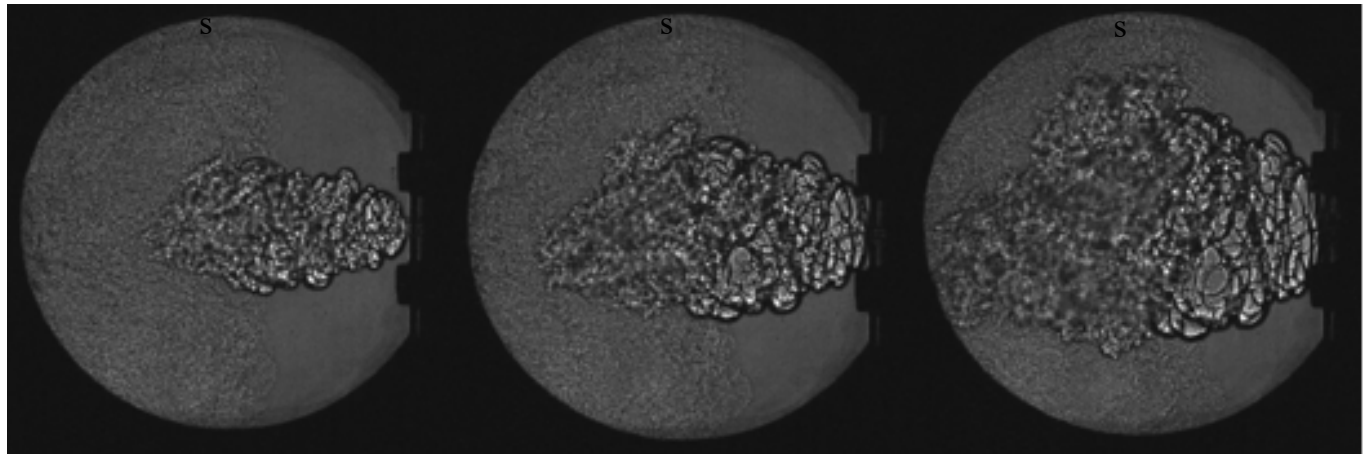

(c) $4.2 \mathrm{~mm} \times 1$ hole $\Phi=0.8,0.3 \mathrm{MPa}$.

$2 \mathrm{~ms}$

$4 \mathrm{~ms}$

$6 \mathrm{~ms}$

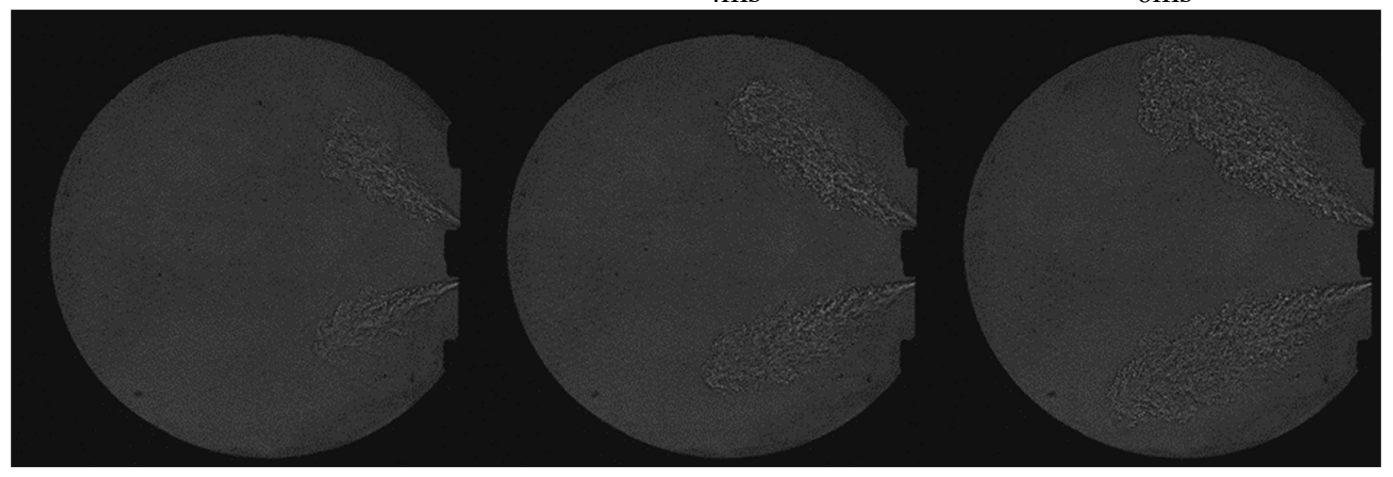

$52 \mathrm{~ms}$

$54 \mathrm{~ms}$

$56 \mathrm{~ms}$

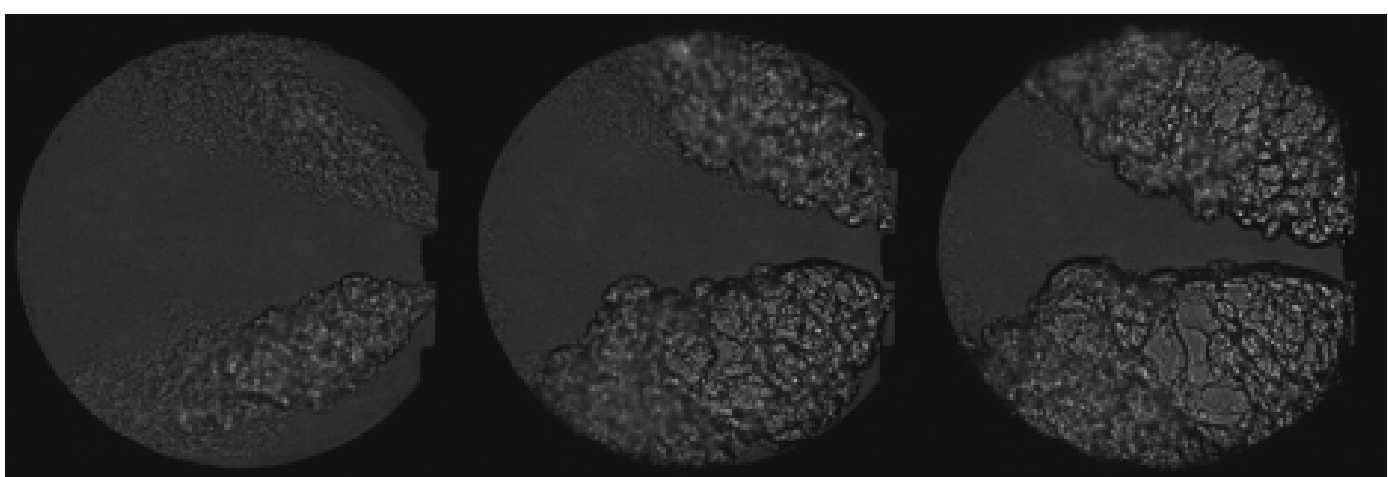

(d) $4.2 \mathrm{~mm} \times 2$ hole $\Phi=1.0,0.3 \mathrm{MPa}$. 
Ueno, Satake, Takayama, Shimada, Tanoue and Moriyoshi,

Transactions of the JSME (in Japanese), Vol.86, No.889 (2020)

$2 \mathrm{~ms}$

$4 \mathrm{~ms}$

$6 \mathrm{~ms}$

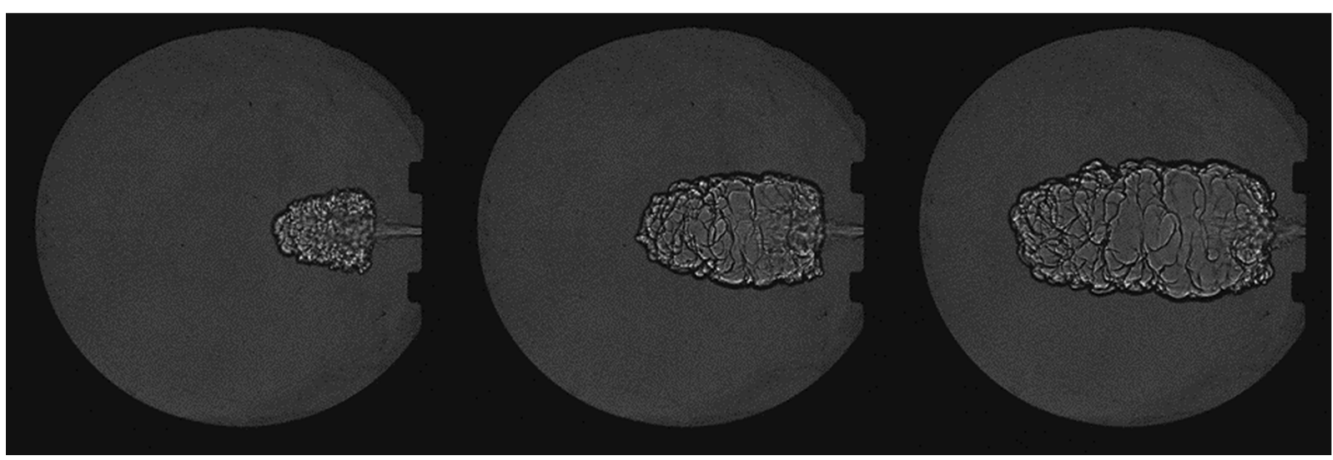

$8 \mathrm{~ms}$

$10 \mathrm{~ms}$

$12 \mathrm{~ms}$

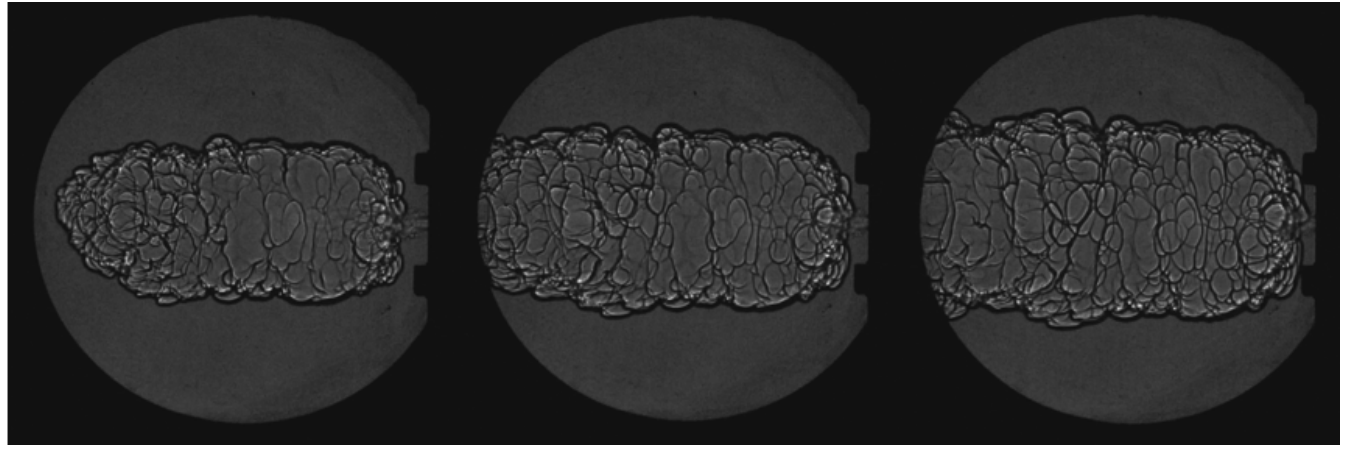

(e) $6.4 \mathrm{~mm} \times 1$ hole $\Phi=1.0,0.3 \mathrm{MPa}$.

Fig.4 Schlieren photographs of the flame kernel formation. 
Ueno, Satake, Takayama, Shimada, Tanoue and Moriyoshi,

Transactions of the JSME (in Japanese), Vol.86, No.889 (2020)

\section{$3 \cdot 2$ 平均噴流速度の比較}

次に本研究では可視化実験により得られた燃焼動画から，各条件において下記のように噴流の進展速度を算出 した．本実験においては噴流の進展速度は図 5(a)に示すように，水平軸上における噴孔部からの噴流先端部の移 動速度とした。また燃焼動画の観察においては，噴流先端が噴孔部から $50 \mathrm{~mm}$ に達するまでには主室内の燃焼が 確認できたため，噴孔部から $50 \mathrm{~mm}$ までの区間で噴流先端の移動速度を比較することにしたまた比較に際して は以下のように平均噴流速度を定義した。図 5(b)において，まず点火後，主室内に噴流を初めて確認した時にお ける噴流先端の到達距離 $L_{0}, t_{0}$ をその時刻とする. 次に噴孔から噴流到達距離が $10 \mathrm{~mm}$ をこえた時の到達距離 $L$

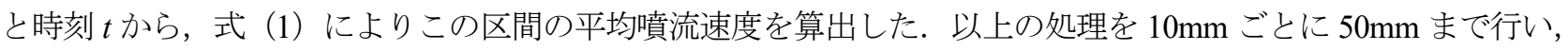
それぞれの区間の平均噴流速度とした。

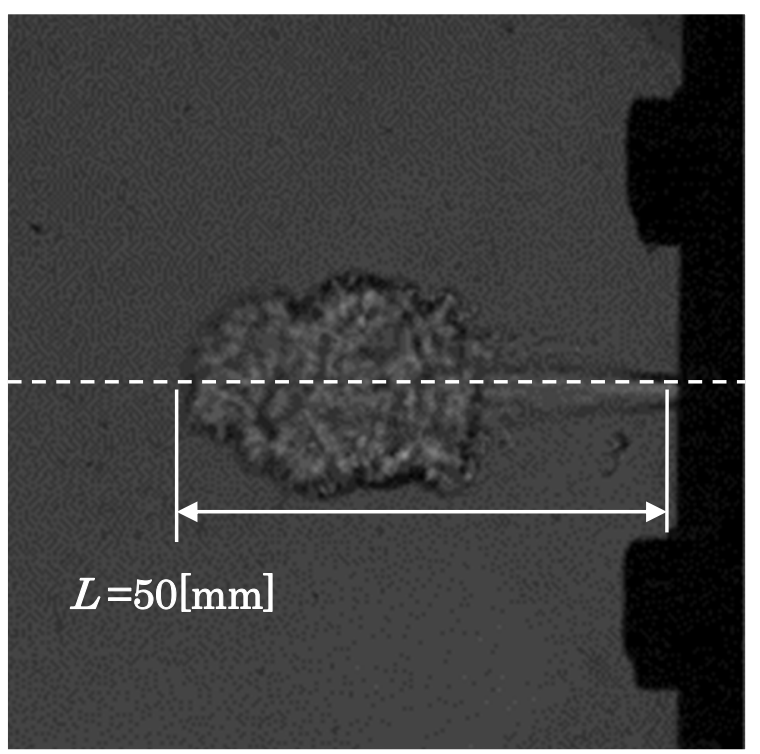

(a) Example of torch flame for estimation.

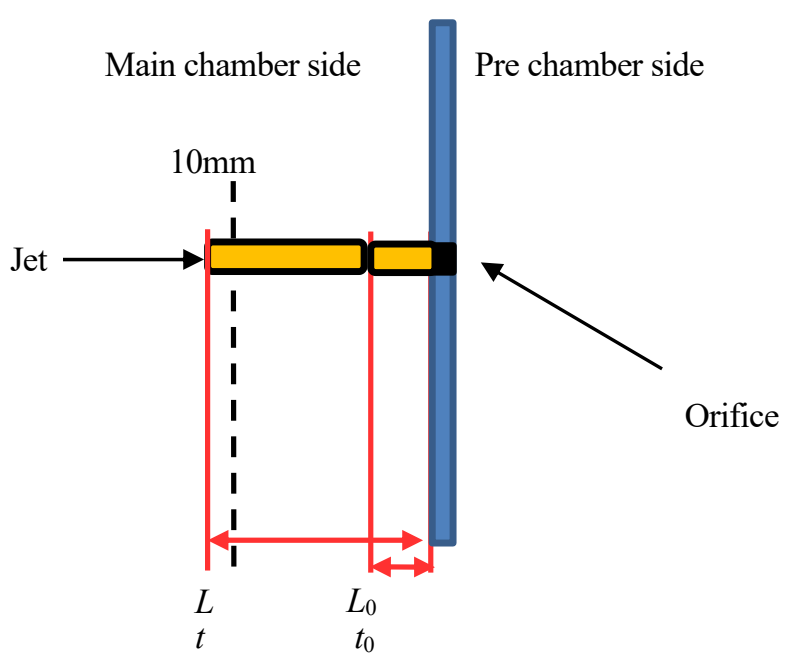

(b) Estimation of jet velocity.

Fig.5 Estimation method of average jet velocity.

$$
V_{i}=\frac{L_{i}-L_{i-1}}{t_{i}-t_{i-1}} \quad i=1,2, \ldots, 5
$$

図 6 に各条件における各区間の平均噴流速度の結果を示寸.図 6 より図 4(a)の当量比 1 , 初期圧力 $0.3 \mathrm{MPa}$ の条 件（X) の噴流速度が最大となっている．これにより，主室内が着火しなかったものと推察される。この条件か ら圧力を上げた条件（○図 4(b)に相当）で若干噴流速度が下がっているが，圧力が上がることで大幅に着火特性 が良くなったことから，初期圧の増加が，主室内の着火特性を改善したものと考える.また，当量比を 0.8 とし た条件（〉図 4(c)に相当）では噴流速度がかなり下がっている。この噴流速度の低下により主室内が着火したも

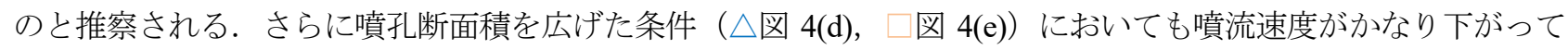
おり，この噴流速度の低下により主室内が着火したものと推察される 
Ueno, Satake, Takayama, Shimada, Tanoue and Moriyoshi, Transactions of the JSME (in Japanese), Vol.86, No.889 (2020)

\begin{tabular}{|c|c|c|c|c|}
\hline \multirow{4}{*}{$\Phi=1.0$} & \multirow{3}{*}{1 hole } & \multirow{2}{*}{$4.2 \mathrm{~mm}$} & $0.3 \mathrm{MPa}$ & $\times$ \\
\hline & & & $0.5 \mathrm{MPa}$ & 0 \\
\hline & & $6.4 \mathrm{~mm}$ & $0.3 \mathrm{MPa}$ & $\square$ \\
\hline & 2hole & $4.2 \mathrm{~mm}$ & $0.3 \mathrm{MPa}$ & $\triangle$ \\
\hline$\Phi=0.8$ & 1hole & $4.2 \mathrm{~mm}$ & $0.3 \mathrm{MPa}$ & $\diamond$ \\
\hline
\end{tabular}

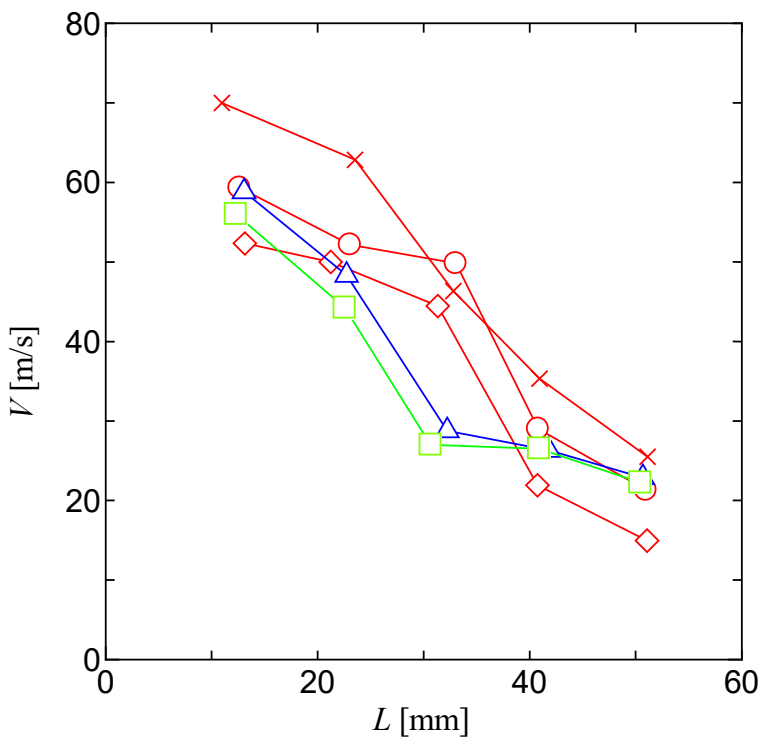

Fig.6 The average jet velocity, as a function of jet length. The jet velocity can affect the ignition in the main chamber.

\section{$3 \cdot 3$ 噴流強度}

最後に本研究では山下らが定義した無次元噴流強度 $G$ （山下他，2017）を用いて副室形状と噴流速度およびそ れによる主室内の燃焼特性への影響を調べた．無次元噴流強度（以降，噴流強度）Gは式 (2) のように定義され る.

$$
G=\frac{4 V_{p}}{n \pi D^{2} D_{B}}
$$

ここで式中のパラメータは副室容積 $V_{p}$, 噴孔径 $D$, 噴孔数 $n$, ボア直径 $D_{\mathrm{B}}$ である. 本研究では副室容積は $V_{p}=85000 \mathrm{~mm}^{3}$, 噴孔数 $n=1$ および $n=2, D_{\mathrm{B}}$ は噴孔部から定容器壁面までの距離と定義し, 一孔では $D_{\mathrm{B}}=200 \mathrm{~mm}$, 二孔では $D_{\mathrm{B}}=180 \mathrm{~mm}$ とした。 ここで噴流強度は副室諸元で決まるパラメータであるため, 噴流強度により噴流速 度が制御でき，さらに噴流速度とで主室内の燃焼の相関が予測できれば，最適な副室諸元を決定できると考えら れる.そこで本論文では各条件における噴流強度を求め, 噴孔から $10 \mathrm{~mm}$ 地点の平均噴流速度との関係を調べた.

図 7 に各条件における噴流強度と平均噴流速度の関係を示寸. グラフより噴流強度 $G$ の増加に伴い, 平均噴流 速度 $V$ が増加する傾向がある．また，噴孔径が小さくなるほど噴流強度が増加し，噴流の平均噴流速度が増加す る. さらに噴孔部の総面積が同じである場合, 噴孔数の増加に伴い, 平均噴流速度が減少している. また同じ噴 流強度においては, 当量比が希薄になると平均噴流速度が減少する傾向がある. 


\begin{tabular}{|c|c|c|c|c|}
\hline $15-1$ & \multirow{4}{*}{1 hole } & \multirow{4}{*}{$4.2 \mathrm{~mm}$} & $0.3 \mathrm{MPa}$ & $x$ \\
\hline & & & $0.5 \mathrm{MPa}$ & 0 \\
\hline \multirow{2}{*}{$\Phi=0.8$} & & & $0.3 \mathrm{MPa}$ & 0 \\
\hline & & & $0.5 \mathrm{MPa}$ & 0 \\
\hline \multirow{2}{*}{$\Phi=1.0$} & \multirow{2}{*}{2 hole } & \multirow{2}{*}{$4.2 \mathrm{~mm}$} & $0.3 \mathrm{MPa}$ & $\Delta$ \\
\hline & & & $0.5 \mathrm{MPa}$ & $\triangle$ \\
\hline \multirow{2}{*}{$\Phi=0.8$} & \multirow{2}{*}{2 hole } & \multirow{2}{*}{$4.2 \mathrm{~mm}$} & $0.3 \mathrm{MPa}$ & $\Delta$ \\
\hline & & & $0.5 \mathrm{MPa}$ & $\Delta$ \\
\hline \multirow{2}{*}{$\Phi=1.0$} & \multirow{2}{*}{1 hole } & \multirow{2}{*}{$6.4 \mathrm{~mm}$} & $0.3 \mathrm{MPa}$ & $\square$ \\
\hline & & & $0.5 \mathrm{MPa}$ & $\square$ \\
\hline \multirow{2}{*}{$\Phi=0.8$} & \multirow{2}{*}{1 hole } & \multirow{2}{*}{$6.4 \mathrm{~mm}$} & $0.3 \mathrm{MPa}$ & $\square$ \\
\hline & & & $0.5 \mathrm{MPa}$ & $\square$ \\
\hline
\end{tabular}

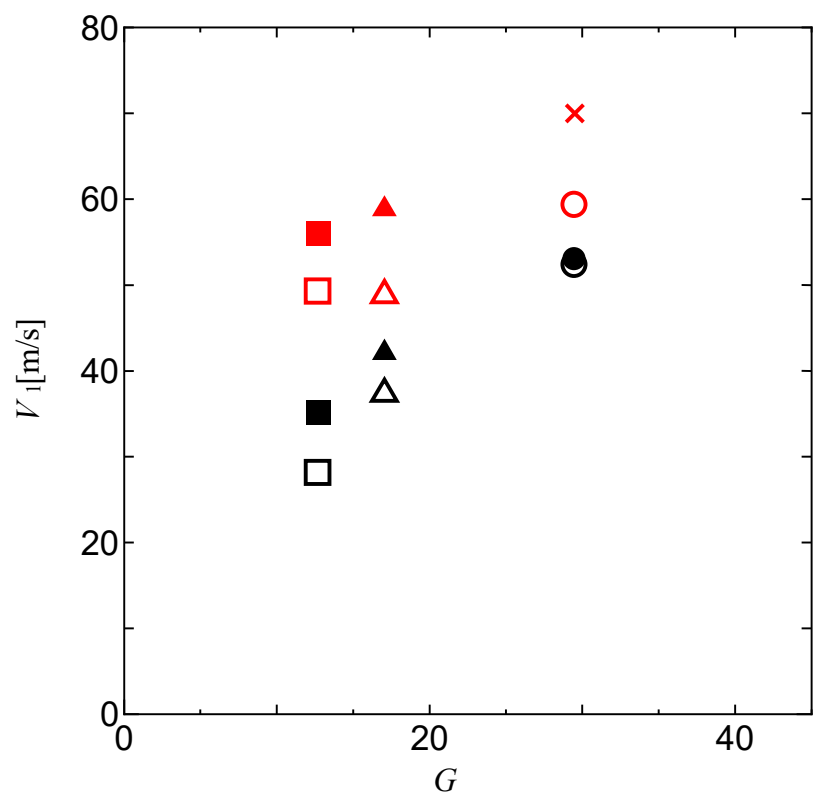

Fig.7 Jet velocity, as a function of jet strength. The average jet velocity $V_{1}$ is found to increase as the jet strength $G$ increases. In addition, the jet strength increases and the average jet velocity of the jet increases as the nozzle diameter decreases.

\section{$3 \cdot 4$ 着火遅れ · 燃焼期間}

本研究では, 実験で得た圧力履歴から熱発生率, 熱発生量を算出することにより, 各条件における主室内の着 火遅れ，燃焼期間の比較を行った．本研究では噴流の主室への噴出開始時刻を，図 8(a)で示すように主室と副室 の差圧が最大值の $20 \%$ に達した時刻と定義した.

燃焼期間の算出方法として， まず定義した噴出開始時刻からの主室の圧力履歴から求めた単位時間当たりの 圧力変化 $d P / d t$ と, 主室内の容積 $V_{\mathrm{m}}=13\left[\mathrm{~m}^{3}\right]$, 比熱比 $k=1.4$ を式（3）に代入し, 熱発生率 $\mathrm{d} Q / \mathrm{d} t$ を導出 (Heywood, 1988)した．さらに求めた熱発生率を積分することにより，熱発生量 $Q$ を求めた.

$$
\frac{\mathrm{d} Q}{\mathrm{~d} t}=\frac{1}{\kappa-1} V_{m} \frac{\mathrm{d} P}{\mathrm{~d} t}
$$

図 8(b)に熱発生率と熱発生量の時間変化の例を示す，本研究では，熱発生量が熱発生量全体の $10 \%$ に達するま での時間を着火遅れ時間 $\tau_{1}$ （FDD : Flame development duration），熱発生量が熱発生量全体の $10 \%$ から $90 \%$ に達す るまでの時間を燃焼期間 $\tau_{2}$ （CD : Combustion duration）と定義し，各条件においてそれぞれ算出を行い，ダムケラ 一数との関係を調べた. 
Ueno, Satake, Takayama, Shimada, Tanoue and Moriyoshi,

Transactions of the JSME (in Japanese), Vol.86, No.889 (2020)

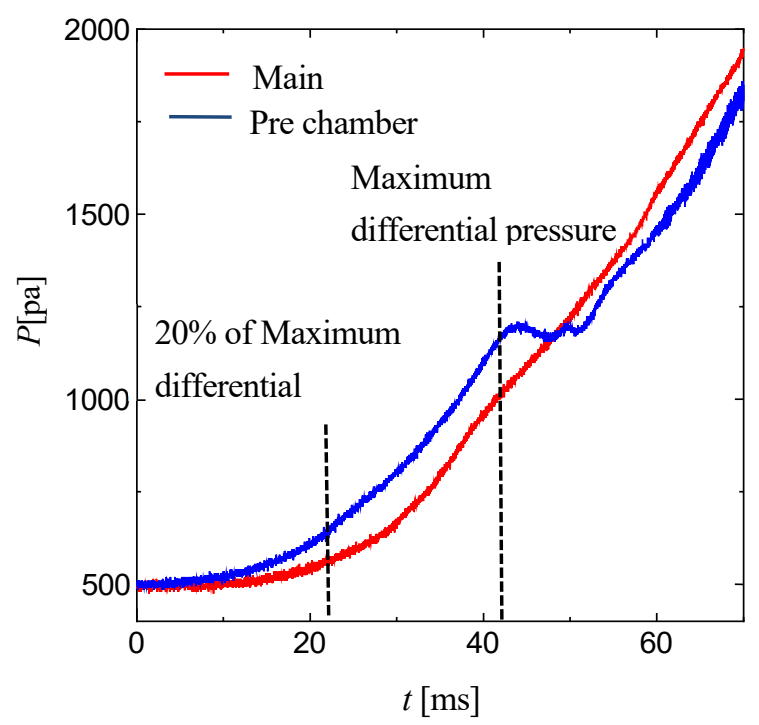

(a) Examples of pressure histories of main chamber and prechamber.

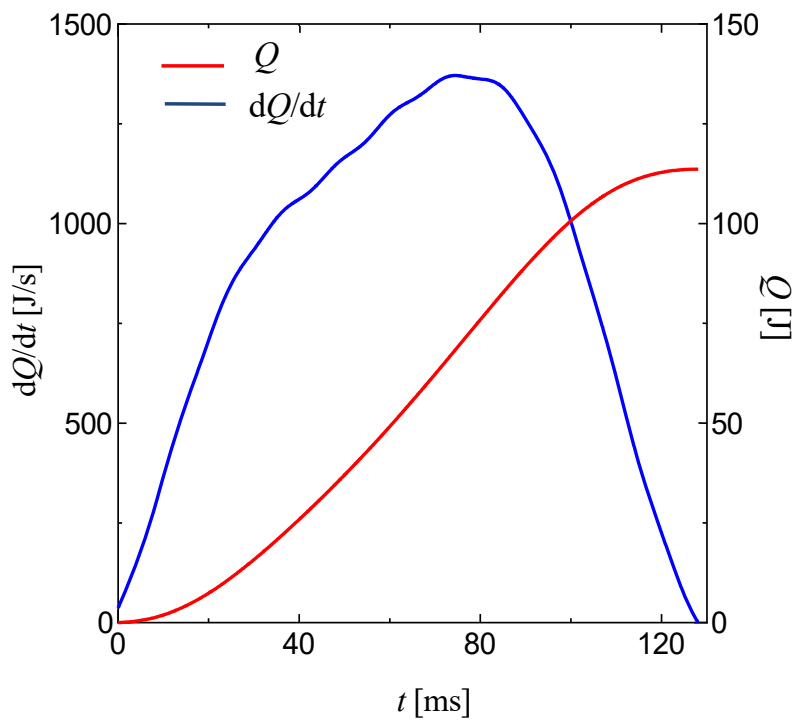

(b) Examples of $\mathrm{d} Q / \mathrm{d} t$ and $Q$ of main chamber.

Fig.8 The definition and calculation method of parameters.

ここでダムケラー数とは，流体力学的な特性時間 $\tau_{\mathrm{f}}$ と化学反応の特性時間 $\tau_{c}$ の比として式 (4) で定義され，流 体力学的な消炎現象を定義づけるものである. ダムケラー数 $D a$ が大きい場合 $\left(\tau_{\mathrm{f}}>>\tau_{\mathrm{c}}\right)$, 化学反応が流体力学 的な現象に比べて十分早いため燃焼は安定し, 逆にダムケラー数 $D \mathrm{a}$ が小さくなると $\left(\tau_{\mathrm{f}}<<\tau_{\mathrm{c}}\right)$ 燃焼は完結せず やがて消炎する (Williams, 2000). 本研究の導出に際しては, 主室に噴出開始から $10 \mathrm{~mm}$ における平均噴流速度 $V$ と，代表長さとして噴孔部から燃焼室壁面までの距離 $D=0.208 \mathrm{~m}$ から式（6）により $\tau_{\mathrm{f}}$ 導出した，また化学反応 の特性時間 $\tau_{\mathrm{c}}$ は Chemkin Pro (ANSYS, 2020)による GRI-Mech3.0 (GRI-Mech 3.0, 2020) を用いた解析から火炎厚 さ $\delta$ と層流燃焼速度 $S_{u}^{0}$ 求め, 式 (5) から求めた.

$$
\begin{aligned}
D a & \equiv \frac{\tau_{\mathrm{f}}}{\tau_{\mathrm{c}}} \\
\tau_{\mathrm{c}} & =\frac{\delta}{S_{u}^{0}} \\
\tau_{\mathrm{f}} & =\frac{D}{V}
\end{aligned}
$$

図 9 にダムケラー数と着火遅れ・燃焼期間それぞれの関係を示す。ここで噴流が壁に到達した後，主室内が燃 焼した条件を赤丸で囲んでいる，図 9 より，噴流が壁に到達してから主室内が燃焼する条件では，着火遅れ $\tau_{1}$ は 遅くなっているが，燃焼期間 $\tau_{2}$ は早くなっている。これは噴流が壁に衝突することで主室内に乱れが生じたため と考えられる. また総じて $D a$ の減少（流速の増加）により着火遅れ $\tau_{1}$ は長くなるが, 燃焼期間 $\tau_{2}$ は短くなる傾向 がある.これは $D a$ の減少（流速の増加）で着火特性は悪くなるが，主室内の乱れが促進され，着火後の燃焼期 間が短縮したものと推察される，しかしながら，上述のように図 9 から，定性的傾向は説明できるが，全ての条 件（噴孔径，当量比，圧力）を定量的に解釈するには至っておらず，今後の課題である. 


\begin{tabular}{|c|c|c|c|c|}
\hline \multirow{5}{*}{$\Phi=1.0$} & \multirow{3}{*}{1 hole } & $4.2 \mathrm{~mm}$ & $0.5 \mathrm{MPa}$ & 0 \\
\hline & & \multirow{2}{*}{$6.4 \mathrm{~mm}$} & $0.3 \mathrm{MPa}$ & $\mathbf{\square}$ \\
\hline & & & $0.5 \mathrm{MPa}$ & $\square$ \\
\hline & \multirow{2}{*}{2 hole } & \multirow{2}{*}{$4.2 \mathrm{~mm}$} & $0.3 \mathrm{MPa}$ & $\boldsymbol{\Delta}$ \\
\hline & & & $0.5 \mathrm{MPa}$ & $\Delta$ \\
\hline \multirow{6}{*}{$\Phi=0.8$} & \multirow{4}{*}{1 hole } & \multirow{2}{*}{$4.2 \mathrm{~mm}$} & $0.3 \mathrm{MPa}$ & ? \\
\hline & & & $0.5 \mathrm{MPa}$ & 0 \\
\hline & & \multirow{2}{*}{$6.4 \mathrm{~mm}$} & $0.3 \mathrm{MPa}$ & $\square$ \\
\hline & & & $0.5 \mathrm{MPa}$ & $\square$ \\
\hline & \multirow{2}{*}{2 hole } & \multirow{2}{*}{$4.2 \mathrm{~mm}$} & $0.3 \mathrm{MPa}$ & $\boldsymbol{\Delta}$ \\
\hline & & & $0.5 \mathrm{MPa}$ & $\Delta$ \\
\hline
\end{tabular}

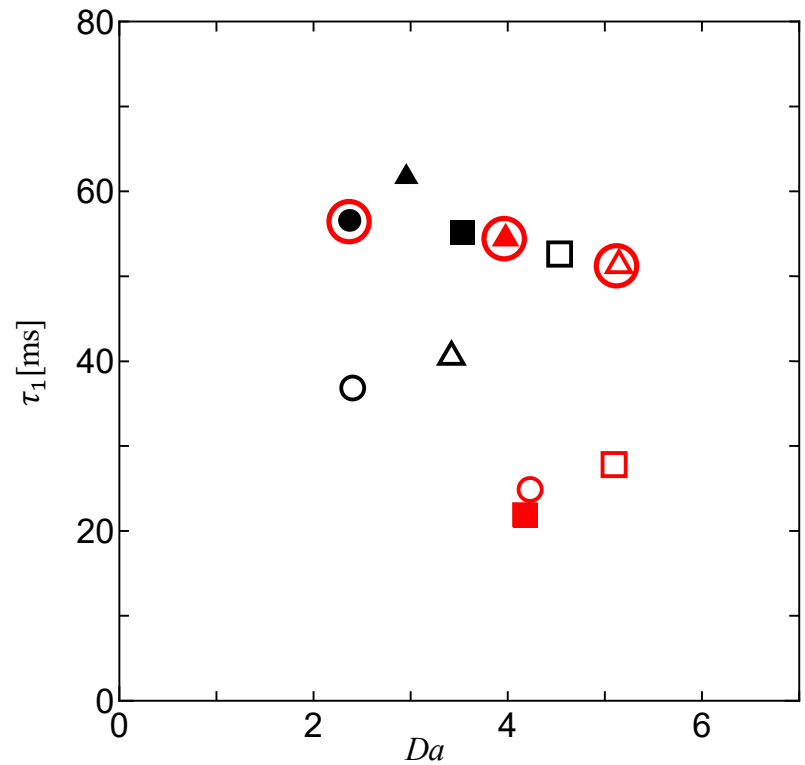

(a) FDD

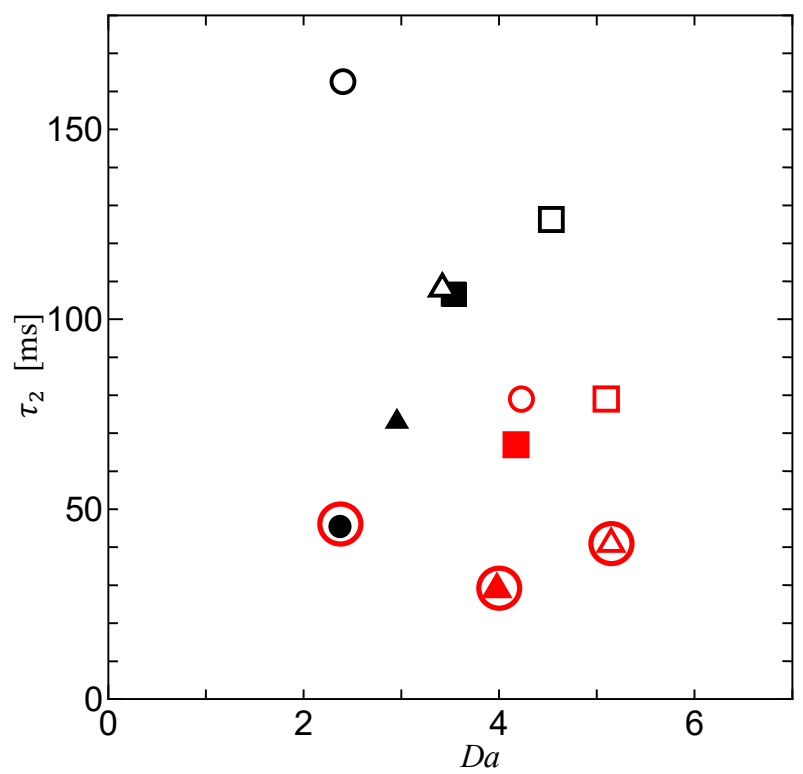

(b) $\mathrm{CD}$

Fig.9 The effect of Damkoeler number on main chamber combustion properties. The ignition delay is found to be longer with decreasing $D a$, while the combustion period tends to become shorter. 
Ueno, Satake, Takayama, Shimada, Tanoue and Moriyoshi, Transactions of the JSME (in Japanese), Vol.86, No.889 (2020)

\section{4. 結 語}

定容燃焼器を用いて副室式点火の基礎燃焼特性について調べ，以下の結論を得た。

1. 燃焼に至らなかった当量比 1 , 初期圧力 $0.3 \mathrm{MPa}$ の条件に対して, 初期圧力を上げることで主室内の燃焼が 確認できた．このことから初期圧の増加は，主室内の着火特性を改善させることがわかった.

2. 燃焼に至らなかった当量比 1 , 初期圧力 $0.3 \mathrm{MPa}$ の条件に対して, 当量比を 0.8 にた条件では噴流速度が かなり低下し，着火に至った。また，噴孔断面積を拡大した条件でも，噴流速度が低下し，主室内の着火が 確認できた。

3. 噴流強度の増加で噴流速度は増加するが，同一噴流強度においても圧力，当量比により，噴流速度は变化す る.

4. 噴流が壁に到達してから主室内が燃焼する条件では，着火遅れは遅くなっているが，燃焼期間は早くなって いる. また総じて $D a$ の減少（流速の増加）により着火遅れ $\tau_{1}$ は大きくなるが，燃焼期間 $\tau_{2}$ は小さくなる傾 向がある.これは $D a$ の減少（流速の増加）で着火特性は悪くなるが，主室内の乱れが促進され，着火後の 燃焼期間が短縮したものと推察される.

\section{謝辞}

本研究は「次世代ガスエンジン・コンソーシアム」の援助により行われた．本研究の一部は科学研究費補助金 No. 26630072 により行われた。また, CHEMKIN の使用に関して ANSYS Academic Partnerships (https://www.ansys.com/academic)のご支援をいただき感謝いたします.

\section{文献}

資源エネルギー庁，日本のエネルギー (2003).

ANSYS, ANSYS Chemkin-Pro, available from $<$ https://www.ansys.com/ja-jp/products/fluids/ansys-chemkin-pro/ $>， （$ 参照 日 2020 年 1 月 24 日)

GRI-Mech 3.0, available from $<$ http://combustion.berkeley.edu/gri-mech/version30/text30.html $>， （$ 参照日 2020 年 1 月 24 日).

Heyne, S., Meier, M., Imbert, B. and Favrat, D., Experimental investigation of prechamber autoignition in a natural gas engine for cogeneration, Fuel, Vol. 88, Issue 3 (2009), pp. 547-552.

Heywood, J. B., Internal Combustion Engine Fundamentals (1988), pp.383-389 McGraw-Hill.

Jamrozik, A., Lean combustion by a pre-chamber charge stratification in a stationary spark ignited engine, Journal of Mechanical Science and Technology, Vol. 29, Issue 5 (2015), pp.2269-2278.

Roethlisberger, P. and Favrat, D., Comparison between direct and indirect (prechamber) spark ignition in the case of a cogeneration natural gas engine, Applied Thermal Engineering, Vol. 22, Issue 11 (2002), pp. 1217-1229.

田上公俊, 加藤義隆, 嶋田諒, 石清水健斗, 宮脇健, 嶋田不美生, 橋本淳, エタノール及び PRF の層流燃焼特性に 関する研究，日本機械学会論文集 B 編, Vol. 78, No. 792 (2012), pp.1432-1440.

Tanoue, K., Kimura, T., Jimoto, T., Hashimoto, J. and Moriyoshi, Y., Study of prechamber combustion characteristics in a rapid compression and expansion machine, Applied Thermal Engineering, Vol.115 (2017), pp.64-71.

Williams, F.A., Progress in knowledge of flamelet structure and extinction, Progress in Energy and Combustion Science, Vol.26, Issue 4-6 (2000), pp.657-682.

山下裕都，名田譲，木戸口善行，賀谷龍，中野秀亮，小林慎一，天然ガス希薄燃焼エンジンの副室より噴出する 既燃ガス噴流進展の解明, 第 28 回内燃機関シンポジウム, 20178038 (2017). 
Ueno, Satake, Takayama, Shimada, Tanoue and Moriyoshi, Transactions of the JSME (in Japanese), Vol.86, No.889 (2020)

\section{References}

Agency for Natural Resources and Energy in Japan, Energy in Japan (2003).

ANSYS, ANSYS Chemkin-Pro, available from < https://www.ansys.com/ja-jp/products/fluids/ansys-chemkin-pro/ > (accessed on 24 January 2020).

GRI-Mech 3.0, available from $<$ http://combustion.berkeley.edu/gri-mech/version30/text30.html $>$, (accessed on 24 January 2020).

Heyne, S., Meier, M., Imbert, B. and Favrat, D., Experimental investigation of prechamber autoignition in a natural gas engine for cogeneration, Fuel, Vol. 88, Issue 3 (2009), pp. 547-552.

Heywood, J. B., The 28th Internal Combustion Engine Fundamentals (1988), pp.383-389, McGraw-Hill.

Jamrozik, A., Lean combustion by a pre-chamber charge stratification in a stationary spark ignited engine, Journal of Mechanical Science and Technology, Vol. 29, Issue 5 (2015), pp. 2269-2278.

Roethlisberger, P. and Favrat, D., Comparison between direct and indirect (prechamber) spark ignition in the case of a cogeneration natural gas engine, Applied Thermal Engineering, Vol. 22, Issue 11 (2002), pp. 1217-1229.

Tanoue, K., Kato, Y., Shimada, R., Iwashimizu, K., Miyawaki, K., Shimada, F. and Hashimoto J., Combustion characteristics of ethanol and PRF laminar flames, Transactions of the Japan Society of Mechanical Engineers, Series C, Vol.78, No.792 (2012), pp.1432-1440 (in Japanese).

Tanoue, K., Kimura, T., Jimoto, T., Hashimoto, J. and Moriyoshi, Y., Study of prechamber combustion characteristics in a rapid compression and expansion machine, Applied Thermal Engineering, Vol.115 (2017), pp.64-71.

Williams, F.A., Progress in knowledge of flamelet structure and extinction, Progress in Energy and Combustion Science, Vol.26, Issue 4-6 (2000), pp.657-682.

Yamashita, Y., Nada, Y., Kidoguchi, Y., Kaya, R., Nakano, S. and Kobayashi, S., Penetration of burned gas issued from a combustion sub-chamber of a lean-burn natural gas engine, The 28th Internal Combustion Engine Symposium, 20178038 (2007) (in Japanese). 